\title{
The influence of soil water potential and soil temperature on the seedling emergence of wheat and barley
}

\author{
MARKKU TENHOVUORI \\ Helsinki University of Technology, Laboratory of Hydrology \\ and Water Resources Engineering \\ SF-02150 ESPOO, Finland
}

\begin{abstract}
The time for $50 \%$ emergence of wheat and barley increases linearly with decreasing matric potential. This increase actually begins at matric pressures above pF 2.7 . The rise in temperature makes emergence faster within the range of minimum temperature $\left(3.1^{\circ} \mathrm{C}\right.$ for wheat and $1.9^{\circ} \mathrm{C}$ for barley) and the temperature where growth begins to slow down (about $31^{\circ} \mathrm{C}$ for wheat and $27^{\circ} \mathrm{C}$ for barley). The optimum range for $50 \%$ emergence was obtained at a matric pressure range of $\mathrm{pF} 1.3-2.7$ or $-5.0--0.20 \mathrm{~m}$ (water column) at a temperature of $10^{\circ} \mathrm{C}$, which quite well corresponds to the situation in Finland during the emergence period in spring. A clear increase can be observed in the required heat sum for wheat and barley when the soil water potential reaches a critical point which was pF 2.8 or $-6.3 \mathrm{~m}$ for wheat and $\mathrm{pF} 2.7$ or $-5.0 \mathrm{~m}$ for barley. The total emergence as a function of matric potential for wheat and barley was determined over a period of 30 days at $10^{\circ} \mathrm{C}$. In the wet side, pF 1.0 can be considered a limit, the total emergence decreasing with lower values. In the dry side, a corresponding decrease can be noticed in total emergence at $\mathrm{pF}$ above 3.0. The water uptake by seeds speeded up with increasing temperature from 10 to $25^{\circ} \mathrm{C}$. Radicles of wheat and barley began to appear when the water uptake by the seed was approximately $50-60 \%$ of the initial weight of the seed. The initial water uptake caused by the moistening of the pericarp due to capillarity was about $3 \%$ for wheat and $5 \%$ for barley at a soil water potential of pF 1.2.
\end{abstract}

Index words: seedling emergence, soil water potential, soil temperature

\section{Introduction}

The two major factors affecting seedling emergence are the moisture and the temperature of the seed bed. In Finland, temperature is the minimum factor for seedling emergence of cereals. Inversely, in arid and semi-arid regions the factor restricting emergence is generally the low moisture content of soil.

Because of the short growing season in Finland, early sowing in spring and fast emergence are very important aspects in obtaining a good yield.

The term soil matric potential is preferable 
to soil moisture when water uptake by plants is discussed, because in different soils the the water uptake by plants is dependent on the amount of energy needed to detach water for the use of plants. In different soils the plants have to exert a similar suctional power toward water despite the fact that the water content of clay for example is many times higher compared to that of sand.

The present paper is dealing with the effect of soil matric potential and soil temperature on the seedling emergence of wheat and barley.

\section{Material and methods}

The grain size of the sand used in the experiments as seed bed was $0.1-0.6 \mathrm{~mm}$. The water retention curve of the sand is presented in Figure 1.

Four methods were used to determine the points of the water retention curve for the soil used as seed bed. The matric potential values $-150--10 \mathrm{~m}$ (water column) were obtained osmotically using a semi-permeable cellulose acetate membrane, pore size $5 \mathrm{~nm}$, immersed in polyethylene glycol solution (PEG,

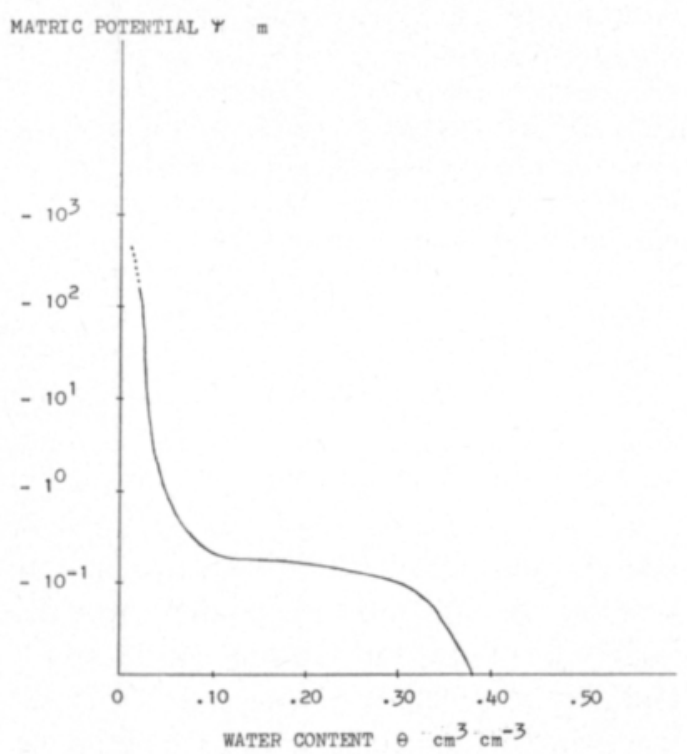

Fig. 1. Water retention curve for the sand used as seed bed in the experiments.
Table 1. The correspondence of PEG solution and matric potential.

PEG $(20000) \mathrm{g} / 100 \mathrm{~g}$ solution Matric potential m

\begin{aligned} & 7.2-10 \\ & 14.0-30 \\ & 17.4-50 \\ & 20.0-70 \\ & 22.9-100 \\ & 25.4-130 \\ & 27.0-150 \\ & \hline\end{aligned}

molecular weight about 20.000). Table 1 shows the correspondence of the PEG solution and the matric potential. The points -1 $\mathrm{m}$ and $-5 \mathrm{~m}$ in the water retention curve were determined by a method developed in the course of the experiments. The sand was put into a small closed plastic vessel and moistened to saturation. Thereafter, pressure was applied to the sand to remove any extra water through the holes under the vessel. The points mentioned above were checked using a water retention curve determination device. The fourth method was used to determine the points $-0.25-0 \mathrm{~m}$ in the water retention curve. The arrangement was based on the capillary rise of sand. The vessel containing sand was laid in another vessel containing water. This allowed the soil to take up water, and matric potential values of $-0.25-0 \mathrm{~m}$ were determined according to the different heights of sand columns. This method did not allow to determine matric pressure values below $-0.25 \mathrm{~m}$, because the capillary rise of the sand was no higher.

The seedling emergence experiments were made with spring wheat (Tähti) and barley (Pokko). The investigations were carried out using three different methods. The first method was used to regulate the moisture of the sand osmotically in the cellulose acetate membrane which allowed capillary rise of water in the funnel where the seeds were immersed into the depth of about $1.5 \mathrm{~cm}$. Each funnel contained 20 seeds. By the second method the effect of low soil moisture on emergence was investigated using the first method described above for determination of 
the water retention curve. The matric potential ranged from -100 to $-10 \mathrm{~m}$ and 10 seeds were immersed into the depth of about $1.5 \mathrm{~cm}$. The third method which was the same as the one described in connection with the water retention curve determination by the fourth method was used to determine the effect of high soil moisture on emergence. Observations were recorded daily. Germination was defined as a seedling of $0.5 \mathrm{~cm}$ emerging from the soil surface. After the experiments the moisture of the seed bed was measured.

In addition to the above, water uptake by seeds was studied by immersing 5 seeds of wheat and barley in the soil at a depth of about $1.5 \mathrm{~cm}$ for different periods of time at $\mathrm{pF}$ 1.2. The moisture was maintained at the desired level by means of the fourth method as was done in the determination of the water retention curve. The seeds were thereafter dried and weighed to determine the amount of water imbibed. The seeds were reimmersed in the seed bed and the experiment continued. Also the number and length of radicles as well as the length of shoot were measured.

The experiments were made at the temperature of $10,15,20$ and $25^{\circ} \mathrm{C}$.

The minimum temperatures for germination were determined at a soil water content of $10-30 \%$ (vol. \%) or $-0.20--0.10 \mathrm{~m}$. The reciprocal of time for $50 \%$ emergence was calculated and a regression line was drawn (FedDEs 1972). The minimum temperatures obtained were $3.1^{\circ} \mathrm{C}$ for wheat and $1.9^{\circ} \mathrm{C}$ for barley. The corresponding heat sums (slopes of the lines) were 70 degree days for wheat and 73 degree days for barley.

\section{Results and discussion}

Figure 2 shows the effect of matric potential and temperature on $50 \%$ emergence for wheat and barley, the time for emergence increasing linearly with decreasing matric pressure from less than $-0.15--0.10$. In fact, the actual increase in the emergence time begins at matric potential approximately below
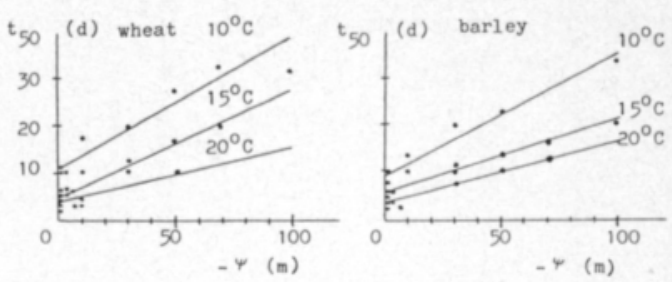

Fig. 2. $50 \%$ emergence of wheat and barley as the function of matric potential and temperature.

$-5 \mathrm{~m}$. A similar linear increase has been noticed e.g. by AurA (1975) for $75 \%$ emergence of sugar beet in fine sand soil at a matric pressure range of about $-130--15 \mathrm{~m}$. The gradual decrease in time for emergence with decreasing matric pressure has been reported by several investigators. Figure 2 shows the effect of temperature on time for emergence, the increase in temperature accelerating emergence. This temperature-related acceleration is a common feature of growth at a range from minimum temperature to the point where growth begins to slow down. For corn the growth of radicle and shoot began to slow down at temperatures exceeding $32^{\circ} \mathrm{C}$ in average (BLACKLOw 1972). The maximum temperature where growth stops is $30-43^{\circ} \mathrm{C}$ for wheat and $30-40^{\circ} \mathrm{C}$ for barley. For wheat the optimum temperature is $15-31^{\circ} \mathrm{C}$ and for barley $19-27^{\circ} \mathrm{C}$ (MAYER \& POLJAKOFF-MAYBER 1975). The emergence of barley is in average faster than that of wheat (Fig. 2). The equations (matric potentials considered positive) presented in Figure 2 are as follows:

$$
\begin{aligned}
\text { WHEAT } \quad \mathrm{t}_{50}^{10}=11,22+0,27 \psi(\mathrm{r}=0,945) \\
\mathrm{t}_{50}^{15}=5,53+0,22 \psi(\mathrm{r}=0,982) \\
\mathrm{t}_{50}^{20}=4,45+0,11 \psi(\mathrm{r}=0,988) \\
\text { BARLEY } \mathrm{t}_{50}^{10}=9,65+0,26 \psi(\mathrm{r}=0,981) \\
\mathrm{t}_{50}^{15}=5,82+0,16 \psi(\mathrm{r}=0,971) \\
\mathrm{t}_{50}^{20}=3,98+0,13 \psi(\mathrm{r}=0,949)
\end{aligned}
$$



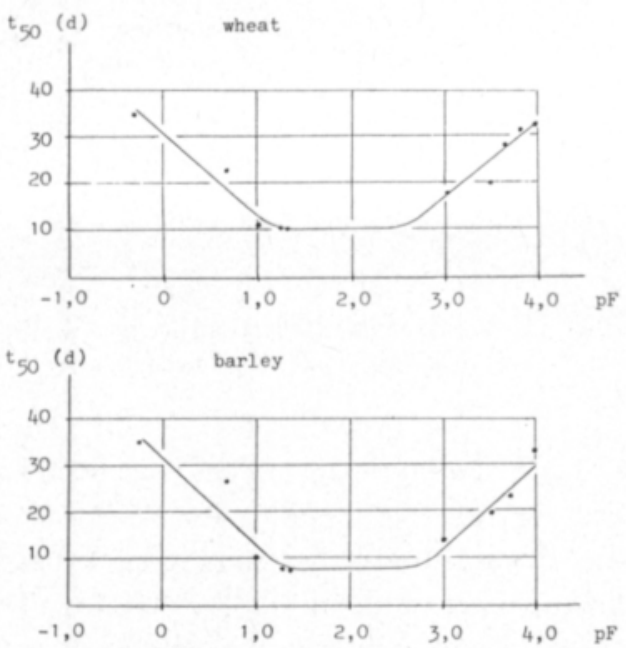

Fig. 3. Effect of soil water potential on the rate of $50 \%$ emergence of wheat and barley at $10^{\circ} \mathrm{C}$.

Figure 3 shows the dependence of soil water potential on the $50 \%$ emergence rate for wheat and barley at a temperature of $10^{\circ} \mathrm{C}$ which produced the most reliable results. FEDDEs (1971) observed slowing down in the emergence rate at $\mathrm{pF}$ values above 2.7 which can also be considered a limit to that of wheat and barley. In the wet side, however, FEDDES reported of the limit for slowing down in the emergence rate of different vegetables to be about pF 2.0 or $-1 \mathrm{~m}$, when this was about $\mathrm{pF} 1,3$ or $-0.20 \mathrm{~m}$ in the present study. According to Figure 3, the optimum emergence rate is achieved at about $\mathrm{pF} 1.3-2.7$ or $-5.0--0.20 \mathrm{~m}$. It is, however, possible that although the water potential of $-0.20 \mathrm{~m}$ still produces fast emergence, it may be too high or too wet for a normal development of seedlings. FEDDES observed the $\mathrm{pF}$ range $1.0-1.5$ to produce too poor seedlings despite otherwise normal germination. These experiments were, however, made on radish and the results differed also in other respects from those of the cereals mentioned above, specifically in the wet side.

In Southern Finland the average temperature in the latter half of May when the emergence of spring cereals is taking place is about $10^{\circ} \mathrm{C}$. Thus Figure 3 gives an idea of the de- pendence of the emergence rate of cereals on the soil water tension in Southern Finland when sowing is carried out normally in about mid-May. During the emergence period, lack of water does not usually restrict emergence. Thus the optimum area in Figure 3 can be considered normal in regard to onset of emergence. It is, however, possible that the soil surface where the emergence takes place can in clay, silt and peat soils become too dry as a result of evaporation, emergence slowing down because of lack of water.

The effect of matric pressure on the heat sum required for $50 \%$ emergence is presented in Figure 4. The heat sum was calculated using the following equation:

$\mathrm{F}=\left(\mathrm{T}-\mathrm{T}_{\min }\right) \mathrm{t}$

where

$\mathrm{T}=$ average temperature ${ }^{\circ} \mathrm{C}$

$\mathrm{T}_{\min }=$ minimum temperature for emergence ${ }^{\circ} \mathrm{C}$

$\mathrm{t}=$ time $\mathrm{d}$

$\mathrm{F} \quad=$ heat sum as degree days ${ }^{\circ} \mathrm{C} \mathrm{d}$

Figure 4 shows a clear increase in the required heat sum for wheat and barley when the matric pressure reaches a critical point which was pF 2.8 or $-6.3 \mathrm{~m}$ for wheat and pF 2.7 or $-5.0 \mathrm{~m}$ for barley which well correspond to the critical value $\mathrm{pF} 2.7$ obtained by FEDDES (1971) for four vegetable crops.

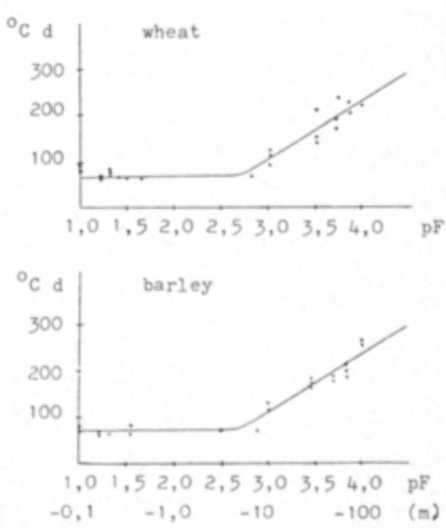

Fig. 4. Development of heat sum for wheat and barley as the function of matric potential for $50 \%$ emergence. 

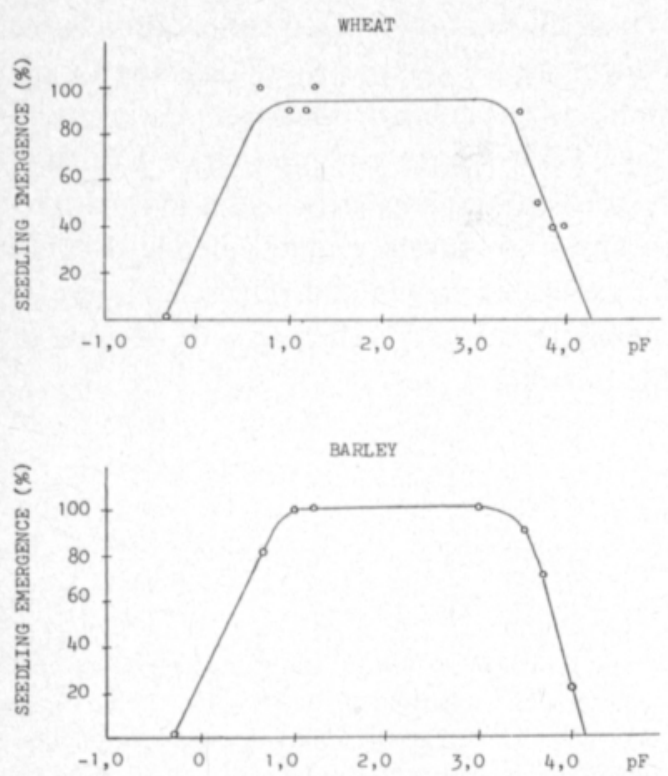

Fig. 5. Total emergence for wheat and barley occurring during 30 days as the function of matric potential at $10^{\circ} \mathrm{C}$.

It is not possible on the basis of the experiments to determine the lowest and highest matric pressures where no more emergence occurs. But within a certain period of time the emergence percentage for total emergence can be determined. Figure 5 shows the dependence of total emergence during 30 days on the matric potential of wheat and barley at a temperature of $10^{\circ} \mathrm{C}$. In both cases, one point clearly differing from the other observations has been excluded. For barley the curve has been drawn directly through the observations, whereas for wheat the curve is partly drawn approximately. The results do not differ much from those obtained by AURA (1975) with sugar beet, although the experiments are not entirely comparable.

Figure 6 shows the imbibition by wheat and barley at the temperatures of 10,20 and $25^{\circ} \mathrm{C}$ at a soil water potential of about $\mathrm{pF}$ 1.2. Compared to the imbibition by corn (Seneca Golden) at $24^{\circ} \mathrm{C}$, for instance, the curve is fairly similar to that for wheat at $25^{\circ} \mathrm{C}$ with the difference that the rise of the imbibition curve of corn is to start with slightly steeper
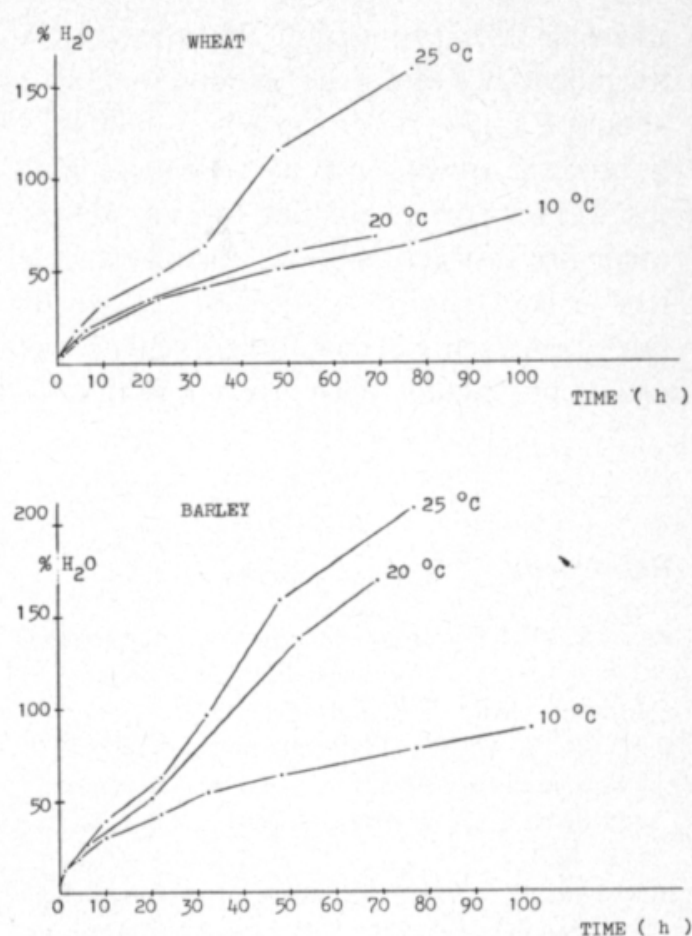

Fig. 6. The imbibition of wheat and barley as the function of time in different temperatures.

(BLACKLOW 1972). The imbibition results for wheat and barley do not show as clearly the point where the exponential phase becomes linear as presented by BLACKLOW for corn (UH 108) at $16^{\circ} \mathrm{C}$ and $24^{\circ} \mathrm{C}$. There are considerable differences between plants and varieties. The matric potential of the seed bed greatly affects also the imbibition by different seeds (HADAS 1970). The course of the imbibition by wheat in the present study was similar to that described by CHING (1972) for wheat during 30 hours. CHING reported of an imbibition slightly faster in average, but this can be ascribed to an initially greater water uptake. The initial water uptake, defined according to BECKER (1960) as the water uptake caused by the moistening of the pericarp because of capillarity occurring during $1 \mathrm{~min}$, was in the present study about $3 \%$ for wheat and $5 \%$ for barley. BLACKLOW reported an initial water uptake of $6 \%$ by corn.

In conclusion, in Finnish conditions it is essential for efficient seedling emergence of 
wheat and barley in spring that the soil matric potential is within the optimum range, i.e. about pF $1.3-2.7$ or $-5.0--0.20 \mathrm{~m}$. It is, however, possible that $\mathrm{pF} 1.3$ is still slightly too wet for normal seedling to occur despite otherwise fast germination. Already a small rise in soil temperature greatly affects the rate of emergence in conditions like those prevailing in Finland. With efficient drainage it is possible to affect the soil temperature in the emergence period, thereby shortening for instance the ripening of wheat and barley by 10 days. Which is of great importance in Finland because of the short growing season. Also by means of irrigation seedling emergence could be promoted in Finland during some years mainly in silt, clay and peat soils because of the possible drying of top soil.

\section{References}

AURA, E. 1975. Effects of soil moisture on the germination and emergence of sugar beet (Beta vulgaris L.). J. Scient. Agric. Soc. Finl. 47. 70 p.

BLACKLOW, W.M. 1972. Mathematical description of the influence of temperature and seed quality on imbibition by seeds of corn (Zea mays L.). Crop Sci. 12: 643-646.

BLACKLOW, W.M. 1972. Influence of temperature on germination and elongation of the radicle and shoot of corn (Zea mays L.). Crop Sci. 12: 647-650.

CHINo, T.M. 1972. Metabolism of germinating seeds. In: Seed Biology, 2: 103-218. New York.

Feddes, R.A. 1971. Water, heat and crop growth. 184 p.
Wageningen.

FEDDES, R.A. 1972. Effects of water and heat on seedling emergence. J. Hydrology 16: 341-359.

HaDAS, A. 1970. Factors affecting seed germination under soil moisture stress. Israel J. Agric. Res. 20: $3-14$.

Mayer, A.M. \& Poljakoff-Mayber, A. 1975. The germination of seeds. $192 \mathrm{p}$. Oxford.

Tenhovuorı, M. 1986. Kuivatuksen ja kastelun vaikutus viljakasvien itämiseen. Thesis $86 \mathrm{p}$. Otaniemi.

Ms received September 10, 1986

\section{SELOSTUS}

\section{Maaveden potentiaalin ja maaperän lämpötilan vaikutus vehnän ja ohran itämiseen}

\section{Markku Tenhovuori \\ Teknillinen korkeakoulu \\ Vesitalouden laboratorio \\ 02150 Espoo}

Kokeissa tutkittiin kevătvehnăn (Tähti) ja ohran (Pokko) itämisen riippuvuutta maaveden potentiaalista ja maan lămpötilasta.

Kasvualustana kăytetyn hiekan raekoko vaihteli vălillä $0,1-0,6 \mathrm{~mm}$. Hiekan vedenpidătyskäyrän măărittämisessả kảytettiin neljăă menetelmảă, joista kahta sovellettiin myős varsinaisiin itämiskokeisiin. Matrikpotentiaalin arvot $-150--10 \mathrm{~m}$ v.p. saatiin osmoottisesti, kun hiekka pantiin puolilăpăisevăn selluloosa-asetaattikalvon sisäăn. Systeemi upotettiin polyetylenglykoliliuokseen (PEG), jonka molekyylipaino oli noin 20000 . Tällöin eri liuosväkevyyksillă saatiin kasvualustassa aikaan halutunlainen matrikpotentiaalin arvo. Varsinaisissa itămiskokeissa käytettiin tăllä menetelmällä potentiaalin arvoja $-100--10 \mathrm{~m}$ v.p. Vedenpidătyskăyrăn pisteet $-1 \mathrm{~m}$ ja $-5 \mathrm{~m}$ mäăritettiin kokeiden yhteydessă kehitetyllă menetelmăllă, jossa hiekka pantiin pieneen suljettuun muoviastiaan ja saatettiin paineen alaiseksi, jolloin ylimaaărăinen vesi päăsi pois astian alapuolelle olevista rei'istă. Tătă ennen hiekka oli ollut vedellă kyllästetyssă tilassa. Varsinaisella $\mathrm{pF}$-käyrän määrityslaitteella saatiin vielă pisteiden $1 \mathrm{~m}$ v.p. ja $5 \mathrm{~m}$ v.p. paikkansapitävyys tarkistet- 
tua. Neljănnellă menetelmăllă mäăritettiin vedenpidătyskăyrăn pisteet $-0,25-0 \mathrm{~m}$ v.p. Tămă perustui veden kapillaariseen nousuun maassa. Eri korkuisilla hiekkapatsailla saatiin haluttu potentiaali. Tätä järjestelyä käytettiin myös itămiskokeissa ja siemenen vedenottoa selvittävissä kokeissa. Itämiskokeissa kảytettiin 1,5 cm:n kylvősyvyyttă ja kymmentă siementả kutakin potentiaaliarvoa kohti. Itămisen katsottiin tapahtuneen, kun n. 0,5 $\mathrm{cm}$ taimesta oli tullut esiin. Havainnot tehtiin päivittäin ja kokeen jălkeen mitattiin kylvőalustan kosteus. Siemenen vedenottoa tutkittaessa 5 vehnăn ja ohran siementă upotettiin 1,5 cm syvyyteen eri pituisiksi ajoiksi pF-arvon ollessa 1,2 . Siemenet nostettiin maasta, kuivattiin, punnittiin ja pantiin takaisin maahan, jonka jälkeen koetta jatkettiin. Tässă yhteydessă laskettiin myös alkeisjuurten lukumaaără ja pituus sekă verson pituus. Edellă mainitut kokeet tehtiin lămpötiloissa $10,15,20$ ja $25^{\circ} \mathrm{C}$.

Itämisen minimilämpötila mäăritettiin kosteuspitoisuuksissa $10-30$ til. $\%$ eli matrikpotentiaalin arvoilla $-0,20--0,10 \mathrm{~m}$ v.p. siten, ettă laskettiin erilaisilla lămpötila-arvoilla $50 \%$ itămisajan kăănteisarvo ja năiden kautta piirrettiin regressiosuora, jonka kulmakerroin ilmaisee lämpösumman astepăivină.

Vehnän ja ohran itämisaika pitenee suoraviivaisesti matrikpotentiaalin pienentyessä $n .-5 \mathrm{~m}$ v.p. pienemmistă arvoista lähtien. Lămpötilan nousu saa aikaan orastumisen nopeutumisen orastumisen minimilämpötilasta siihen asti, kunnes saavutetaan lämpötila, jossa kasvu alkaa hidastua. Minimilämpötiloina kăytettiin laskelmissa koetuloksista saatuja arvoja $3,1^{\circ} \mathrm{C}$ vehnälle ja $1,9^{\circ} \mathrm{C}$ ohralle. Vastaavat lämpösummat ovat 70 astepäivăă vehnälle ja 73 astepåivảả ohralle. Lämpötila, jonka jălkeen kasvu alkaa hidastua on $\mathrm{n} .31^{\circ} \mathrm{C}$ vehnälle ja n. $27^{\circ} \mathrm{C}$ ohralle.

Suomen olosuhteita itämisjakson aikana keväisin melko hyvin vastaavassa $10^{\circ} \mathrm{C}$ lämpötilassa saatiin optimialueeksi $50 \%$ itämisnopeudelle noin pF-alue $1,3-2,7$ eli $-5,0--0,20 \mathrm{~m}$ v.p. Vehnă ja ohra vaativat selvăsti suuremman lămpösumman kun maaveden jännitys saavuttaa tietyn ns. kriittisen arvon. Vehnän kriittiseksi arvoksi saatiin aineiston perusteella $\mathrm{pF} 2,8$ eli n. $6,3 \mathrm{~m}$ v.p. ja ohran pF 2,7 eli n. 5,0 m v.p.

Lămpötilassa $10^{\circ} \mathrm{C}$ măăritettiin 30 paaivăn kuluessa tapahtuva vehnăn ja ohran kokonaisităminen matrikpotentiaalin funktiona. Märällä puolella voidaan $\mathrm{pF}$-arvoa 1,0 pitäă arvona, jota suuremmissa kosteuksissa kokonaisitåminen alkoi văhentyă. Kuivalla puolella voidaan vastaavasti havaita kokonaisitämisen văhenemistă sen jälkeen kun pF-arvo noin 3,0 on ylittynyt.

Siemenen vedenoton nopeus kasvoi kokeiden perusteella lämpötilan kohotessa $10^{\circ} \mathrm{C}$ :sta $25^{\circ} \mathrm{C}$ :een. Alkeisjuuri ilmaantui vehnäăn ja ohraan vaiheessa, missă siemenen vedenotto oli n. 50-60\% siemenen alkuperäisestă painosta. Siemenen seinämän kostumisesta kapillaarisuuden johdosta tapahtuva siemenen vedenotto alussa oli vehnăllă n. $3 \%$ ja ohralla n. $5 \%$ maaveden potentiaalin ollessa n. pF 1,2 siemenen vedenottoa selvittăvissă kokeissa.

Käytännössã on oleellista tehokasta itämistă ajatellen pyrkiă pitămăăn vehnăn ja ohran kohdalla matrikpotentiaali Suomen olosuhteissa kevaalllă optimialueella, joka on n. pF 1,3 - 2,7. Jo pieni maan lämpötilan kohoaminen vaikuttaa positiivisesti itämisnopeuteen Suomen oloissa. Tehokkaalla kuivatuksella voidaan vaikuttaa sopivan kosteuspitoisuuden ylläpidon lisăksi maaperăn lämpötilaan siten, ettă viljakasvit tuleentuvat nopeammin, millă on tärkeă merkitys Suomen lyhyestä kasvukaudesta johtuen. Myös kastelulla olisi mahdollista joinakin vuosina edistäă itämistả Suomenkin oloissa pảäasiassa joillakin hiesu-, savi- ja turvemailla. 